\title{
University-based teacher education in the field of tension between the academic world and practical experience in school: a Norwegian case.
}

Eyvind Elstad (Department of Teacher Education and School Development, University of Oslo, Norway)

DOI: $10.1080 / 02619768.2010 .504948$

European Journal of Teacher Education, Volume 33, Issue 4 November 2010 , pages 361 - 374

\section{Introduction}

A common feature of teacher education in Norway is the tension between the different elements of profession-based proximity to the school and the academic-driven research base (NOKUT 2006). The tension between academic and practical orientations is often experienced by the staff of teacher education institutions and student teachers (Murray and Male 2005). This article addresses an issue familiar to teacher education institutions that have merged with a university. Using the pedagogical teacher education section (abbreviated to TE) affiliated with the University of Oslo (abbreviated to $\mathrm{UO}$ ) as an empirical example, this article analyses how the tension between the worlds of Minerva and the school emerged: first, resistance from academia, later, integration of teacher education into the Norwegian university system.

When the first Norwegian university was established at the beginning of the nineteenth century, the education of secondary school teachers was one of its functions (Dahl 1964). This programme did not relate, however, to the work of school teaching itself. Nearly 100 years would pass before a theoretical and practical form of teacher education was established in addition to the subject-based courses offered by the university (Harbo 1969). That the university adopted a course of study in pedagogy in 1907 was due to the efforts of teacher interest groups and state authorities. The nineteenth-century university hierarchy did not regard the educational component of TE as a core function of the university (Collett 1999). This position was a symptom of the university officials' understanding of the areas in which a university ought to be engaged.1 With the exception of a short intermezzo in the period 1918-1922, PSO did not feature as part of the UO's activity until 1988. Although the university and the teacher education section were separate institutions, a number of adjustments in favour of the needs of schooling gradually became apparent in the university's scheme of study, not least in the content of courses (Jordell 1976). The university was conscious of its role as supplier of academic content in teacher education. But the coupling between the academic and pedagogic elements of teacher education remained weak. In the closing years of the 1960s, the question of incorporation was raised by the university and in 1988 CTE was formed as a fusion between two sections of the university, despite vigorous opposition on the part of some staff from both the teacher education and the university institutes that would be affected by the new university organisation (Elstad 2008). The academic staff who run the university-based teacher education programme find themselves in a tension between adapting to the expectations for engagement in research and the need for profession-based proximity to educational practice in schools (Murray 2005,2008 ). The latter is necessary if the university's teacher education programme is to be regarded as relevant among school staff, educational bureaucrats, and aspiring teachers. This demands a broad insight into practical school-based issues. On the other hand, it is expected in Norway that university staff should produce published research following academic conventions. 
Teacher educators are 'a particular type of academic' (Murray and Male 2005) who are located partly as academics and partly as educationalists (Livingston, McCall, and Morgado 2009). The tensions between teacher education's obligation to a professional proximity to the field of practice and the obligation to adapt to the expectations of the university are demanding to resolve due to the divergence of expectations and interests in the worlds of university and school (Maguire 2000).

Table 1. Teacher education at University of Oslo.

\begin{tabular}{|l|l|l|l|}
\hline Time & $\begin{array}{l}\text { Teacher education section } \\
\text { (TE) }\end{array}$ & Abbreviated to & Administered by \\
\hline $1908-1987$ & Pedagogic Seminary in Oslo & PSO & $\begin{array}{l}\text { The Ministry of Church and } \\
\text { Education* }\end{array}$ \\
\hline $1988-1995$ & $\begin{array}{l}\text { Centre for Teacher Education } \\
\text { and In-service Training }\end{array}$ & CTE & $\begin{array}{l}\text { The Council of University of } \\
\text { Oslo }\end{array}$ \\
\hline $1996-$ & $\begin{array}{l}\text { Department of Teacher } \\
\text { Education and School } \\
\text { Development }\end{array}$ & DTE & $\begin{array}{l}\text { Faculty of Education, } \\
\text { University of Oslo }\end{array}$ \\
\hline
\end{tabular}

Note. *Except 1918-1922 when PSO was a part of the University of Oslo.

The features and challenges in university teacher education differ from one country to another (Morberg and Eisenschmidt 2009). The purposes of this article are to contribute to a better understanding and to discuss, interrogate, and identify problems inherent in the tensions between academia and the proximity to the field and the need for robust knowledge production through research and the 'tips for teachers' approach.

\section{Methodology}

The following comparison between the goals, values, and institutional position of individuals and groups, along with the constraints that regulate their actions, is based on historical source material,2 surveys, field notes, and verbal sources.3 School and academia serve here as ideal types (Weber 1964) by which we can classify phenomena. The analytical framework serves the purpose of creating a framework for understanding the institutional dynamics because of divergent values, norms, and preferences.

\section{Different cultures}

It is expected that academic staff who work at an institution such as UO's current teacher education programme should maintain 'a professional relationship with school-based practice' in order to maintain the practical relevance of the teacher education programme (UO 2005). The majority of TE personnel have themselves previously been school teachers and as such have been exposed to the norms, interests, and values inherent in schools. The cultures of a university institute are unlike those of the teaching world and it is therefore reasonable to describe them as different cultures (Murray, Swennen, and Shagrir 2009) or epistemologies (Joram 2007). 
A typical career path leading to a permanent position as a university academic in Norway begins nowadays after the completion of a doctorate (Bleiklie, Høstaker, and Vaboslash 2000). A doctoral student in today's TE environment is exposed to academic values through participation in the doctoral programme. The assumption is that doctoral students will be socialised and infected with the values and norms of the university (Hage 1980). When university staff are socialised, this means that central opinions, norms, and values that reside in the organisation will be cheapened (Schein 1988). But 'voice' or 'exit' are other possible outcomes of social influencing (Hirschman 1970). Within the university as an institution reside inbuilt values and interests that in significant respects are distinct from the values and interests of the school as a field of practice (Joram 2007).

The political sector has an interest in using higher education as an instrument for social interests (Olsen 2007). The institutional dynamics of the TE environment are thereby influenced by both academic demands and consideration for society's requirement for a TE programme with relevance to schools.

The academic reputation of both the individual scholar and the institute itself appear as a goal and premise for a meritocratic collegiate establishment (Whitely 1984). Well-established actors or institutional policies set the standards for practice. This collegiate society of scholars can be interpreted as protectors of an academic realm (Engwall 1992) to academia to prevent the ingress of inadequately qualified persons or institutions.

Those who are incorporated into the school as an organisation go through a socialisation process that can mean that the newcomer adopts the dominant standpoints, norms, and perspectives of the school world. The latter teaching culture is no single entity but is differentiated according to school type, subject, and level (Stodolsky and Grossman 1995). Certain meritocratic values may well be present, though not to such an extent as in the university sector. The social and cultural identity of the school is thereby distinct from that of the university sector (Bourdieu 1990). The school's interest in TE relates to the need for adequate recruitment of new teachers and in-services (NNC 2002). For this, the practical relevance of TE will be of central significance.

Among school staff there is a significant spread of opinion in respect to the relative importance of the various competing goals for TE and teaching practice. Individual examples can be found of students being told: 'Here, other things count. Forget everything you have learned on campus'. A survey that looked at the attitudes of teachers to pedagogical theory and to TE as supporting a skills environment in school-improvement projects initiated by governing bodies (Elstad and Turmo 2009) . This is an indication of teachers' negative opinions of educational research, and this also indicates a slight preference for tricks. 
Table 2. Teachers' opinions of TE and educational research.

\begin{tabular}{|l|l|l|}
\hline Items & Mean & SD \\
\hline $\begin{array}{l}\text { TE should primarily teach us more tricks that } \\
\text { work well in teaching }\end{array}$ & 4.46 & 1.80 \\
\hline $\begin{array}{l}\text { TE should primarily tell us teachers how we } \\
\text { can do our job better }\end{array}$ & 3.81 & 1.63 \\
\hline $\begin{array}{l}\text { TE should primarily assess whether the } \\
\text { school has succeeded with its improvement } \\
\text { work }\end{array}$ & 3.95 & 1.53 \\
\hline $\begin{array}{l}\text { Pedagogic research is not applicable in } \\
\text { practice }\end{array}$ & 2.85 & 1.44 \\
\hline $\begin{array}{l}\text { Educational research is too remote from } \\
\text { school-based practice }\end{array}$ & 3.52 & 1.46 \\
\hline
\end{tabular}

Notes: On a seven-point Likert scale, 74 teachers at TE's practice schools responded to questions (that included 1 = strongly disagree and 7 = strongly agree, while 4 is a neutral mid-point - 'neither agree nor disagree'); the teachers gave their opinion on how TE ought to be involved in schoolimprovement projects. Response rate about $54 \%$.

\section{Teacher education}

In the 1970s, a discussion emerged about incorporating TE as a part of the university's organisation. Within PSO, there was a pronounced scepticism during the 1970s against this.4 The top officials of UO, however, expressed an increasingly strong wish for PSO to become part of UO. When, in 1986, a negotiating committee suggested the amalgamation of PSO with some small parts to form a new university centre (CTE), this suggestion resulted in internal opposition from within both UO and PSO. PSO had a low status among the staff of the three university departments that were proposed to amalgamate with PSO. The committee's recommendation (Recommendation 1986, 52-3) emphasises that 'clinical' pedagogic qualifications should be a requirement for appointment in the teacher education section. The first test of how this requirement for clinical qualifications should be interpreted in practice was the assessment for professorial standing, to which the assessment committee applied traditional qualification criteria. The criteria for appointment to permanent academic posts over time has become similar to that of equivalent posts in the other departments of the university. 5

When CTE was established, only one member of staff at PSO had a doctorate, while all the staff in other university departments had doctorates as a matter of course. CTE thereby had a mixed culture: partly norms, values, and interests that were close to the school culture and partly employees with a research identity. The university affiliation created pressure to adapt to the university's expectations without losing the professional proximity of TE to the practical field of work in schools. 
Since 1988, a number of structural adjustments have been made by CTE/DTE to adapt to the university environment. A process of new appointments and promotions has increased the number of professors from one in 2002 to 11 in 2009. Since 1938, general didactics has had its parallel as a university subject. The area of subject didactics, however, lacked an established point of reference within UO. When CTE was established, the methods teachers did not enjoy status parity with the professors of established university subjects. The challenge was therefore one of strengthening the research and research qualifications of the staff (Recommendation 1986). After 1992, there was a clear institutional expectation that new research associates would follow a doctoral programme. During 1972-1985, PSO had 11 such associates, two of whom took doctorates (throughput 18\%).

After the associates were given access to the doctoral programme, two out of six took doctorates (throughput 33\%) from 1986-1997, while 10 out of 12 took doctorates from 1998-2006 (throughput $83 \%)$. Over time, the range of subject didactics has increased. These examples show clear adaptation to the structures of the university. Adaptation to the university's expectations is also seen in the tendency towards increased research. On the other hand, there are developments within TE that point in another direction. Since 1988, not a single member of the permanent PSO staff has taken a doctorate or received a promotion. The PSO staff construe their role in a more non-academic manner. Several of them have expressed a negative attitude to academic research (and a positive commitment to the school sector). 6 The new CTE/DTE was highly differentiated and had a divided culture. During 1988-2009, it can be shown that TE staff have written a substantial quantity of school textbooks, thus continuing the PSO tradition. TE has the highest proportion of junior lecturing staff in all of UO's various institutes, while no leader of TE (1922-2009) has taken a doctorate.

Many of the subject lecturers operate alone within their fields and are not clearly anchored in an academic team. This may imply that some teacher education cultures are not able to engage students in robust academic discipline and, to some extent, fail to use research to enhance practice. A small minority of the teacher educators do not view themselves as 'academics'. Such attitudes can be taken as supporting a practicality/technique approach. On the other hand, student teachers are looking for tips to help them master the role of teacher in their practice periods (Svartdal 2001; Hamilton, Loughran, and Marcondes 2009). A book that is used in the student teacher programme was described as follows in a review by an eminent pedagogue: 'It also happens that articles contain suggestions concerning how work can be carried out around a particular theme. Some of the articles come close to what one might be tempted to describe as a "recipe"' (Telhaug 2007, 96-7). The giving of recipes is seen as beyond the pale among academically inclined teacher educators. 7 On the other hand, teaching faculty provide student teachers with concrete, oral examples of teaching during lectures and by written material. Practically inclined teacher educators may make the accusation that the majority of research is insufficiently relevant to the exercise of the teaching function in the school. The university's emphasis on excellent but impractical research and credentialism can contribute to creating among this group a feeling of inferiority in relation to staff from other parts of the university. Empirical support for this can be drawn from a staff survey: $15 \%$ of teacher educators reveal that they are not proud of working at UO; $16.8 \%$ of them experience a lack of respect and acknowledgement for the work they carry out (UV 2009).

It is those who succeed with academic production who, to a greater extent than previously, achieve recognition in official forums. TE's policy of publishing league tables of persons with most publication points contributes to emphasising meritocratic values.8 This is also reflected in 'research-based 
apportioning of resources' (DTE 2009a) and the establishment of research groups, including active researchers (UV 2008). Fifty-nine per cent of staff are of the opinion that the establishment of research groups enhances academic collaboration (UV 2009). The negative side of the development is revealed in the $46.2 \%$ who consider that there is 'too much exposure to negative competition between colleagues' and $61.9 \%$ regard it as 'difficult to meet faculty expectations in regard to publishing' (UV 2009). In this staff survey, 83.3\% replied that they, to a greater or lesser extent, 'have the opportunity to participate in staff-development measures'. The systems for allocating research grants contribute to reinforcing the hegemony of academic-meritocratic values. The extent to which this development can influence the morale of staff who do not view themselves as 'academics' is an area for future research.

\section{Subject didactics}

'Subject methodology' was an academic term used by educationalists from 1907-1975 (Bue 1957; Sjøberg 2001). In the 1970s, a new term, 'subject didactics', was employed to mark a change (Aringlvik 1974). The 1970s subject-didactic research and development work at PSO was seen partly as an adaptation to the internal professional norms of academia, but the relative prestige of subject didactics (as compared with university subjects) was/is low.9

Subject didactics have an unresolved place in the subject classification of academia in Norway (Sjøberg 2001). Subject didactic identity can be connected to both pedagogic and subject bases. There have been tensions between the assessments for professorial standing of staff belonging to academic disciplines and staff belonging to subject didactic disciplines.10 This has been pointed out in evaluations of the system. It has been commented that applicants 'feel wrongly placed when the individual's application has been assessed by national committees for chemistry, mathematics, or physics rather than a special committee for natural sciences didactics' (NAHEI 1995, 38).

Being a member of university staff is regarded as having a higher status than being a teacher but, within UO's internal hierarchy, being a teacher educator does not enjoy a high status. On the other hand, UO has accepted an initiative to establish a research programme that invites researchers from other faculties to collaborate on school-relevant research together with TE staff.11 Another indication of UO's acceptance of TE is that the administrative responsibility for the management of the teacher programme was transferred from the Council of UO to the Faculty of Education in 2009. A third example was the election of a TE professor into the university's senior management team.12 These three examples indicate that teacher education staff are being enabled to move into university-wide roles and responsibilities.

The costs of teaching practice within TE have been constantly under-financed since 2002.13 The under-financing has, however, created pressure on teacher education management, which in turn has pressured the TE staff.

The Faculty of Education has equality with the other faculties of $\mathrm{UO}$ and exerts an influence on the decision-making processes of the university. On the other hand, the faculty ( 0.9 publication points per capita) does not manage to achieve the university's target figures for research (UO 2009). UO has ambitious targets for excellence in research and ranks highly among European universities. The average number of publication points per member of academic staff at TE in 2008 was less than half that of TE's academic sister, IER (DTE 2009a).14 In TE's strategic plan, TE has 'a special remit for 
educationally-relevant research' the goal of which is to 'increase publication in international journals' (DTE 2009a).

Portions of the financing of TE are connected to publication points. To a certain degree, staff members who are engaged in contract research manage to publish their research through channels that yield publication points. This contract activity is thus a big player in research and income generation.

When UO expects excellence in research, local pay awards are made to support the kind of research required by academic journals. There is a pattern that high academic production is significantly weighted, while those who are excellent in teaching receive little recognition in terms of pay, promotion, and progression. The road to salary increase leads primarily through academic activity. Twenty-seven per cent of permanent staff at TE, however, occupy posts at the junior lecturer level. Since 2009, a senior staff programme has been in operation, under which $10 \%$ of work time can be devoted to work to achieve the qualifications required for academic appointment. In some instances, TE has given support and sabbaticals to staff in junior positions, but the new strategy for sabbaticals is to award them to 'active researchers' (DTE 2009a).

The TE faculty draws on research to inform and enhance the quality, competence, and capacity of their students as the results of research are to some extent integrated into teaching. There are constrained benefits from being within a research culture. An educational reform at UO (2001) requiring participation and the submission of student work along the way has contributed to a greater intensity of study. Many students choose TE in the final stage of their period of university study and the association of student teachers finds it difficult to raise enthusiasm among the great majority of students. A new tendency is for more students to be accepted into the teacher programme, which involves school placements each year. A development of this sort contributes to the students developing a stronger identity towards the teaching profession while studying.

\section{Doorkeeper mechanism}

One mechanism of the university's institutional behaviour is the repelling of intruders who do not agree or fall in line with the established university disciplines. This is a key issue when we look at the attitudes of university staff over the period 1813 and towards the establishment of a TE section as part of the university's activities (Harbo 1969). The reason for repelling appears to change over time.

On the other hand, experience shows that new subjects can be established and grow without the exclusion mechanism seeming to make itself felt. Two examples are the subjects we now call 'information science' (which grew out of an academic milieu at the Mathematical Institute at UO) and 'media science'. In such cases, resistance can be sparked by competition for resources, but resistance to the new subjects does not seem to be as intense as in the case of an intruder. It seems to be easier to start a new area when it builds on insiders as a driving force. In the case of TE, the Institute of Educational Research (IER) was not anxious to integrate TE into its activities when the question of the assimilation of PSO was raised in the 1970s, and very powerful resistance resulted when, in 1986, a negotiating committee suggested the fusion of the university's academic section of educational research (IER) with PSO. 


\section{Socialisation mechanism}

A theoretical expectation is that a recruit entering an organisation will adapt to the norms and values of the organisation (Schein 1988). University recruitment is selective in the sense that it is fundamental to the university system that recruitment be based on open competition and that the best are chosen. Doctoral studies can contribute to the socialisation of individuals. When this happens, the new recruit generally adopts the norms and values of the research community (Hage 1980). This hypothesis has a measure of support in the available empirical material. Completed doctorates at DTE lead to publishing activity and thereby adaptation. New recruits with PhDs have more academic credibility. There is a significant difference in the adaptation of expectations in terms of qualifications for those recruited before and after the incorporation into UO. Furthermore, there are differences in terms of the extent of publishing activity for these two categories of recruits.

On the other hand, differentiated adaptations are created, which are reinforced by the fact that DTE has also recruited junior staff, such as junior lecturers, and this career path has been developed to include lecturer/senior lecturer and reader. The strategic plan for 2009-2013 calls for a strong expansion in readerships and for a focus on developing school-based expertise in respect of these (DTE 2009a). While CTE/DTE primarily concentrated in 1988-2008 on adaptation to the university's appointment structure, the direction is now more complex. When PSO was incorporated into UO in 1988, the two were separated by a no-man's land. Over the period 1994-2006, bridges were built between the two by means of doctoral projects, academic output, and master's programmes.

\section{Strategic planning}

At a time of growing interest in the incorporation of TE into the university's organisation, a former dean became the new leader of the TE section. The incorporation into UO in 1988 created the basis for strategic priorities, better financing, and the expansion of courses and posts.

\section{The institution's self-dynamic}

As I have described, the fusion between PSO and the university sections led to a partly mixed and partly divided culture and a cohabiting of different identities, which has created tensions between a school-practice orientation and a university-practice one. It is possible to envisage a strengthened relationship between academia, teacher training, and school in the sense that research-based knowledge can be seen as an instrument for achieving improvements in the quality of schooling (Cochran-Smith 2005). The opposite dynamic is also conceivable: a reduced relationship between university and educational authorities because of the government looking elsewhere for reports and legitimacy. In such a case, the future role of the university would be in the form of academic courses and teacher training, but relatively little besides. This tendency can be observed in Norway: nonuniversity bodies are able to offer products that, to a substantial degree, lack the attributes of university products. It is the combination of partly coincidental and partly diverging interests of such institutions as the university, authorities, and schools that makes the question of the future path of TE so interesting for those seeking a better understanding of its institutional dynamics (Olsen 2007). 


\section{Status of teachers and teacher educators}

The status of teachers has been reduced in Norway over time, but the need for teacher recruitment is growing strongly (Aamodt and Turmo 2008). The status of the teaching profession is well below that of engineers, nurses, and artisans (TSN 2009). In the course of several decades, the entry qualification for teacher training has fallen 15 and the proportion of unqualified teachers in the schools is growing. The authorities have been obliged to set a minimum qualifying grade for entry into teacher training from secondary school and steps have been taken to make the teaching profession more attractive in Norway. A teacher survey looked into the extent to which teachers felt valued as employees.

The teachers' feeling of a lack of appreciation by society and their employers is also expressed in media reports as well as in research (Lindblad, Johannesson, and Simola 2002), which raises the question of whether the teacher's role is turning from one connected with trust to one connected with control, measurement, and de-professionalisation.

UO's attitude towards the place of TE in the university has changed over time. Significant differences are apparent between the attitudes of the nineteenth century university and those of UO's leadership in the 1970s and subsequently. A more pragmatic relationship with the needs of society is now strongly apparent at UO. On the other hand, there have been differences between ground-level attitudes and those of the UO senior management. Some resistance at the ground level is undeniable:

It is often the most research-heavy areas that lose out. The Faculty of Education was established by a fusion of college-type practical pedagogic education (TE) and the Institute of Educational Research (IER). Despite the establishment being driven by Norway's premier research university for twelve years there are such great problems that a member of the university council called it 'a catastrophe area'.16

\section{Comparison of teacher training and medicine}

Academic terms used in campus activities at TE are little used in teaching practice in Norway. It is interesting that the tension between academia and proximity to the field does not exist for the medical faculty (which also requires such proximity) within the university because medical faculty and the field of practice share the same medical language. One can ask whether this is connected with status and tradition. To assert that medicine has a 'historic claim' to academic respectability (Henke 1978) is not accurate in a Norwegian context. Medicine had a relatively low internal status within $\mathrm{UO}$ in the nineteenth century. Hospital practice was, however, an integral part of medical training from the beginning. It is true that in the twentieth century the internal and external status of doctors increased, and in 2009 doctors were at the top of the status hierarchy in Norwegian society (TSN 2009) and in the upper echelons of the internal status hierarchy of UO. 
Table 3. Teachers' feeling of appreciation by society.

\begin{tabular}{|l|l|l|}
\hline Items & Mean & SD \\
\hline As a teacher I feel truly valued by society & 3.10 & 1.80 \\
\hline $\begin{array}{l}\text { I believe that my employer gives me recognition for the } \\
\text { effort I make on behalf of the school }\end{array}$ & 2.52 & 1.31 \\
\hline
\end{tabular}

Notes: A teacher survey amongst the teachers at 11 schools which were partners within TE. The total response rate was $54 \% . \mathrm{N}=242.1=$ strongly disagree and $7=$ strongly agree, while 4 is a neutral mid-point - 'neither agree nor disagree'.

While many specialisations within medicine have monoparadigmatic characteristics, specialist fields within teacher education are characterised by 'a fragmented view of knowledge' (Ben-Peretz 1995, 546). Only to a limited extent can we view educational research as a cumulative collaborative activity. This is also reflected in the textbooks studied by student teachers: Piaget and Vygotsky still rule supreme as 'the big two' in the books used in Norwegian TE.17 Such distinctive features create difficult conditions for developing a professional language in academia and in education. Teachers' conceptualisation is rather personal and particular (Labaree 2003), and the academic specialisations of teacher education play little role in shaping the technical language of teaching in Norway. Lortie $(2002,123)$ asserted that teachers lack a common professional language. The 'clinical pedagogic qualifications' which it was once hoped would emerge in TE have not had impact.

An important factor that has contributed to this development is that there is hardly any job rotation between teacher educators and teachers. TE staff maintain very limited contact with schools, almost only through school visits where their function is to observe the teaching carried out by trainee teachers. Whereas 40 years ago, there were plans for TE to run a practice school, a significant distance from the practice school is inherent in today's situation.18 This stands in marked contrast to medicine: 'One of the exciting aspects of the extensive academic publishing in medicine is that individuals constantly shift roles between being researcher/author, reader/practitioner and even editor or referee'.19

The powerful administrative management in the Norwegian health sector is at one with the interests of the medical profession: doctors look after special training and participate in decisions about who should receive or lose licenses to practice. $20 \mathrm{It}$ is in large measure the same individuals who move between positions and functions in the Faculty of Medicine and in the field of practice.

\section{Concluding remarks}

In this article, I have discussed, interrogated, and identified problems inherent in the tensions between academia and the proximity to the field. There are serious concerns about combinations of university-based and school-based learning in Norway and elsewhere (Grossman 2008). However, other promising combinations of university-based and school-based learning (van Velzen, Bezzina, and Lorist 2009) and networks of professional development of teacher educators (Swennen and van der Klink 2009) are identified. For those who believe in positive synergies between academia and practice in terms of teacher training, job rotation, a common technical language/professional 
orientation, and an administrative management that complements the professional orientation would counteract the present deplorable conditions in Norway. There are great challenges: teacher recruitment and teacher training in Norway are in a state of crisis. Job rotation for teacher educators could be a first step towards influencing a desirable professional orientation, but it would take time to influence developments in the school in such a direction. Teachers do not behave as a profession nor are they treated as a profession. The conclusion has to be that the difference between academia and practice is significant within teacher education in Norway, at least in one institution. In future research, we need a sharper focus on the complexity in the inherent issues involved in the tensions between academia and the proximity to the field.

\section{Acknowledgements}

I am grateful to K.O. Jordell and anonymous referees for comments on earlier drafts of this article. Many thanks to A. Turmo for help with measurements.

\section{Notes}

1. This is also reflected in the fact that professional schools in engineering, dentistry, business administration, veterinary science, and geology were placed outside UO.

2. Archive of the Faculty of Education.

3. I have conducted nine in-depth semi-structured interviews with key informants of the PSO/CTE/DTE story.

4. Interviews.

5. Archive of the Faculty of Education.

6. Interviews. Ducharme (1993), Hatton (1997), Ducharme and Agne (1989) and Lanier and Little (1996) have also identified subgroups of teacher educators who continue to adhere to their attitudes and identities as ex-school teachers combined with a negative attitude to academic research.

7. It is striking that concrete examples of teaching methods and concrete illustrations of good teaching are almost absent from textbooks used in TE (Engelsen 2001).

8. The number of applicable academic publication points at DTE reported in to the statistics of the Council of Universities and Colleges: from 41 in 2004, to 40 in 2005 and so to 50 in 2006, 58 in 2007 and 39 in 2008. Points per capita in TE are: 2005: 0.98, 2006: 1.17, 2007: 1.06, 2008: 0.64 (UO 2009).

9. Interviews.

10. 'For almost two decades there has been a certain tension between researchers within general didactics and subject didactics, based on the somewhat different training and competences of the two groups. This schism is particularly unfortunate for subject didactics because researchers in this field are not only suspected by researchers within general didactics, they may also be mistrusted by colleagues within their main discipline(s)' (Stroslashmnes, Roslashrvik, and Eilertsen 1997, 251).

11. www.uio.no/english/research/interfac/kis/ 
12. www.aftenposten.no/kul und/article3012928.ece

13. www.uniforum.uio.no/nyheter/2005/09/krise-for-laerarutdanninga-ved-uio.html

14. In 2008 DTE had 0.64 point per capita while IER had 1.35 point per capita.

15. One explanatory factor is that Norway spends a below-average share of the wealth on teacher salaries: www.oecd.org/dataoecd/39/62/1840245.pdf

16. Professor Kristian Gundersen, UO. Morgenbladet 29 January 2008.

17. Vygotsky and Piaget loom large in the most-used textbook (Imsen 2005). About $16 \%$ of the text concerns these two.

18. However, many teacher educators in other parts of Europe do this role transfer very successfully even in similar conditions (Swennen, Shagrir, and Cooper 2009). Some promising partnerships are identified (van Velzen, Bezzina, and Lorist 2009).

19. E-mail from Professor Magne Nylenna. In literary and cultural terms, there is little difference between academic doctors and medical practitioners (Mennin 2009).

20. Medicine has codes of conduct. 'The profession of teacher educators could benefit from standards being developed within, and by, the community of teacher educators' (Swennen and van der Klink 2009, 222).

\section{References}

1. Aamodt, P. O. and Turmo, A. (2008) Forskjeller i laeligrerkompetanse i videregaringende skole: konsekvenser for elevenes laeligringsutbytte?. Norsk pedagogisk tidsskrift 93 , pp. 122-134.

2. Aringlvik, T. (1974) Undervisningslaeligre 1: Aktuelle synspunkter og problemer Nordisk forlag, Copenhagen

3. Ben-Peretz, M. Anderson, L. W. (ed) (1995) Curriculum of teacher education programs. International encyclopedia of teaching and teacher education pp. 543-547. Elsevier, Oxford

4. Bleiklie, I. , Høstaker, R. and Vabø, A. (2000) International study of higher education Norway Jessica Kingsley Publishers, London

5. Bourdieu, P. (1990) Homo academicus Polity Press, Cambridge

6. Bue, T. (1957) Pedagogisk metodikk Gyldendal , Oslo

7. Cochran-Smith, M. (2005) Teacher educators as researchers: Multiple perspectives. Teaching and Teacher Education 21 , pp. 219-225. [ERA - General Abstracts]

8. Collett, J. P. (1999) Historien om Universitetet i Oslo Universitetsforlaget, Oslo

9. Dahl, H. (1964) Laeligrerutdanningen ved Universitetet i Oslo fra 1814 til i dag Universitetsforlaget, Oslo

10. DTE (2009a) Strategisk plan 2009-2012 University of Oslo , Oslo 
11. DTE (2009b) Publikasjonspoeng per enhet University of Oslo, Oslo

12. Ducharme, E. (1993) The lives of teacher educators Teachers College Press, New York

13. Ducharme, E. and Agne, R. Wisniewski, R. and Ducharme, E. (eds) (1989) Professors of education: Uneasy residents of academe. The professors of teaching pp. 67-86. New York Press, Albany

14. Elstad, E. Knudsen, G. and Evenshaug, T. (eds) (2008) Universitetets lærerutdanning i spenningsfeltet mellom akademia og skolen. Universitetet og lærerutdanningen pp. 205-238. Unipub Forlag, Oslo

15. Elstad, E. and Turmo, A. Hovdenak, S. S. , Eggen, A. B. and Elstad, E. (eds) (2009) Indikatorer for å unders $\varnothing$ ke den menneskelige faktorens betydning for skoleutvikling. Kunnskapsløftet fra ord til handling pp. 166-178. University of Oslo, Oslo

16. Engelsen, B. U. Elstad, E. (ed) (2001) Er enkeltfagenes didaktikk tilstrekkelig?. Fagdidaktikkens identitet og utfordringer pp. 59-80. Acta Didactica, Oslo

17. Engwall, L. (1992) Mercury meets Minerva. Business studies and higher education. The Swedish case Pergamon Press, Oxford

18. Grossman, P. (2008) Responding to our critics: From crisis to opportunity in research on teacher education. Journal of Teacher Education 59 , pp. 10-23.

19. Hage, J. (1980) Theories of organizations. Form, process, and transformation Wiley, New York

20. Hamilton, M. L. , Loughran, J. and Marcondes, M. I. Swennen, A. and van der Klink, M. R. (eds) (2009) Teacher educators and the self-study of teaching practices. Becoming a teacher educator. Theory and practice for teacher educators pp. 205-218. Springer, Dordrecht

21. Harbo, T. (1969) Teori og praksis i den pedagogiske utdannelse Universitetsforlaget, Oslo

22. Hatton, E. (1997) Teacher educators and the production of bricoleurs: An ethnographic study. Qualitative Studies in Education 10 , pp. 237-257.

23. Henke, D. (1978) Colleges in crisis Penguin, Harmondsworth

24. Hirschman, A. O. (1970) Exit, voice and loyalty. Responses to decline in firms, organizations, and the state Harvard University Press, Cambridge

25. Imsen, G. (2005) Elevens verden Universitetsforlaget, Oslo

26. Joram, E. (2007) Clashing epistemologies: Aspiring teachers', practicing teachers', and professors' beliefs about knowledge and research in education. Teaching and Teacher Education 23 , pp. 123135.

27. Jordell, K.Ø. (1976) Filolog eller lærer. Fors $\varnothing$ ksrådet for skoleverket, Oslo

28. Labaree, D. F. (2003) The peculiar problems of preparing educational researchers. Educational Researcher 32 , pp. 13-22. 
29. Lanier, J. and Little, J. Wittrock, M. (ed) (1986) Research on teacher education. Handbook of research on teaching pp. 527-569. Macmillan, New York

30. Lindblad, S. , Johannesson, A. and Simola, H. (2002) An inevitable progress? Educational restructuring in Finland, Iceland and Sweden at the turn of the millennium. Scandinavian Journal of Educational Research 46 , pp. 325-339.

31. Livingston, K. , McCall, J. and Morgado, M. Swennen, A. and van der Klink, M. R. (eds) (2009) Teacher educators as researchers. Becoming a teacher educator. Theory and practice for teacher educators pp. 191-204. Springer, Dordrecht

32. Lortie, D. (2002) Schoolteacher: A sociological study University of Chicago Press, Chicago

33. Maguire, M. (2000) Inside/outside the ivory tower: Teacher education in the English academy. Teaching in Higher Education 5 , pp. 150-165.

34. Mennin, S. P. Dent, J. A. and Harden, R. M. (eds) (2009) Academic standards and scholarship. A practical guide for medical teachers pp. 398-405. Elsevier , Oxford

35. Morberg, Aring. and Eisenschmidt, S. Swennen, A. and van der Klink, M. R. (eds) (2009) Secondphase induction for teacher educators: Challenges and possibilities. Becoming a teacher educator. Theory and practice for teacher educators pp. 103-113. Springer , Dordrecht

36. Murray, J. (2005) Re-addressing the priorities: New teacher educators and induction into higher education. European Journal of Teacher Education 28, pp. 67-85.

37. Murray, J. (2007) Countering insularity in teacher education. Academic work on pre-service courses in nursing, social work and teacher education. Journal of Education for Teaching 33 , pp. 271291.

38. Murray, J. (2008) Towards the re-articulation of the work of teacher educators in higher education institutions in England. European Journal of Teacher Education 31, pp. 17-34.

39. Murray, J. and Male, T. (2005) Becoming a teacher educator: Evidence from the field. Teaching and Teacher Education 21 , pp. 121-142.

40. Murray, J. , Swennen, A. and Shagrir, L. Swennen, A. and van der Klink, M. R. (eds) (2009) Understanding teacher educators' work and identities. Becoming a teacher educator. Theory and practice for teacher educators pp. 29-44. Springer , Dordrecht

41. NAHEI (1995) 'Jeg ble bedømt som om jeg skulle vært en geolog!' Erfaringer og vurderinger av ordningen med opprykk til professor etter kompetansevurdering The Norwegian Association of Higher Education Institutions, Oslo

42. NNC (2002) Evaluering av praktisk-pedagogisk utdanning ved fem norske institusjoner Network Norway Council , Oslo

43. NOKUT (2006) Evaluering av allmennlærerutdanningen i Norge 2006 NOKUT, Oslo 
44. Olsen, J. P. Maassen, P. and Olsen, J. P. (eds) (2007) The institutional dynamics of the European university. University dynamics and European integration pp. 25-54. Springer , Dordrecht

45. Recommandation (1986) Forslag om å etablere Senter for lærerutdanning og skoletjenester ved Universitetet i Oslo Universitetet i Oslo, Oslo

46. Schein, E. (1988) Organisational socialisation and the profession of management. Sloan Management Review 12 , pp. 53-65.

47. Sjøberg, S. Elstad, E. (ed) (2001) Naturfagdidaktikk - tverrfaglighet som styrke og problem. Fagdidaktikkens identitet og utfordringer pp. 10-33. Acta Didactica, Oslo

48. Stodolsky, S. S. and Grossman, P. L. (1995) The impact of subject matter on curricular activity: An analysis of five academic subjects. American Educational Research Journal 32 , pp. 227-249.

49. Strømnes, Aring.L. , Roslashrvik, H. and Eilertsen, T. V. (1997) Didactical thinking and research in Norway during the four last decades. Scandinavian Journal of Educational Research 41, pp. 237-258.

50. Svartdal, O. Elstad, E. (ed) (2001) Refleksjoner om fagdidaktikkens identitet. Fagdidaktikkens identitet og utfordringer pp. 50-58. Acta Didactica , Oslo

51. Swennen, A. , Shagrir, L. and Cooper, M. Swennen, A. and van der Klink, M. R. (eds) (2009) Becoming a teacher educator: Voices of beginning teacher educators. Becoming a teacher educator. Theory and practice for teacher educators pp. 91-102. Springer, Dordrecht

52. Swennen, A. and van der Klink, M. R. Swennen, A. and van der Klink, M. R. (eds) (2009) Enhancing the profession of teacher educator. Becoming a teacher educator. Theory and practice for teacher educators pp. 219-226. Springer, Dordrecht

53. Telhaug, A. O. (2007) En bok for alle laeligrere. Bedre skole 1 , pp. 96-97.

54. TSN (2009) Laeligrerstatus www.regjeringen.no/nb/dep/kd/dok/rapporter planer/rapporter/2009/larerstatus-mars-2009-tnsgallup.html?id=548817

55. UO (2005) Strategisk plan for UIO 2005-2009 UO , Oslo

56. UO (2009) UV-fakultetets publiseringsstrategi 2009-2013 UO , Oslo

57. UV (2008) Forskergrupper ved Det utdanningsvitenskapelige fakultet UO , Oslo

58. UV (2009) Arbeidsmiljøunders $\emptyset$ kelsen ved UV-fakultetet UO , Oslo

59. van Velzen, C. , Bezzina, C. and Lorist, P. Swennen, A. and van der Klink, M. R. (eds) (2009)

Partnerships between schools and teacher education institutes. Becoming a teacher educator. Theory and practice for teacher educators pp. 59-74. Springer , Dordrecht

60. Weber, M. (1964) Theory of social and economic organization Free Press, New York

61. Whitely, R. (1984) The intellectual and social organization of the sciences Oxford University Press, Oxford 